\title{
Episodic ataxia type 1
}

INSERM

\section{Source}

INSERM. (1999). Orphanet: an online rare disease and orphan drug data base. Episodic ataxia type 1. ORPHA:37612

Episodic ataxia type 1 (EA1) is a frequent form of Hereditary episodic ataxia (EA; see this term) characterized by brief episodes of ataxia, neuromyotonia, and continuous interictal myokymia. 